\title{
Ectoparasites from small mammals from the Cerrado region in the Minas Gerais state, Brazil
}

\author{
Danilo Gonçalves Saraiva ${ }^{1}$, Gislene Fátima da Silva Rocha Fournier, Sarita Pimenta de Oliveira, Maria Ogrzewalska', \\ Edeltrudes Maria Valadares Calaça Câmara², Claudia Guimarães Costa ${ }^{3}$ and José Ramiro Botelho ${ }^{4}$ \\ 'Departamento de Medicina Veterinária Preventiva e Saúde Animal, Faculdade de Medicina Veterinária e Zootenia, Universidade de São Paulo, \\ São Paulo, Avenida Professor Dr. Orlando Marques de Paiva 87, São Paulo, SP, Brazil; danilosaraiva@usp.br; mogrzewalska@gmail.com \\ ${ }^{2}$ Bicho do Mato Instituto de Pesquisa, Rua Perdigão Malheiros 222, Bairro Luxemburgo, MG, Brazil; tudy@bichodomato.net.br \\ ${ }^{3}$ Laboratório de Mastozoologia, Museu de Ciências Naturais PUC Minas, Avenida Dom José Gaspar 290, Bairro Coração Eucarístico, \\ Belo Horizonte, MG, Brazil; cacau@pucminas.br \\ ${ }^{4}$ Laboratório de Ectoparasitos, Universidade Federal de Minas Gerais, Avenida Antônio Carlos 6627, Bairro Pampulha, Belo Horizonte, MG, Brazil; \\ botelho@icb.ufmg.br
}

Recibido 27-IX-2011 Corregido 16-XI-2011 Aceptado 4-XII-2011

\section{ABSTRACT}

Besides being an important component of the ecosystem and part of biodiversity, some ectoparasites of small mammals have economic and public health importance, but there are not many studies about them in Brazil. The objective of the present study was to investigate the prevalence of infestation of ectoparasites associated with small mammals from the Cerrado biome in the National Park Serra do Cipó, Minas Gerais State, Brazil. Small mammals were captured from April to September 2007. In total, 95 mammals were caught representing nine species: Six of these species belong to the order Rodentia: Cerradomys subflavus Wagner 1842, Nectomys squamipes (Brants 1827), Thrichomys apereoides (Lund 1939), Rhipidomys mastacalis (Lund 1840), Necromys lasiurus (Lund 1841), Oligoryzomys nigripes Olfers 1818, and three to the Order Didelphimorphia: Gracilinanus agilis (Burmeister 1854), Marmosops incanus (Lund 1840) and Didelphis albiventris (Lund, 1841). Ectoparasites from five orders were collected: Ixodida, Gamasida, Phthiraptera, Siphonaptera and Diptera. The following species of ectoparasites were found: Amblyomma sp., Laelaps paulistanensis Fonseca 1936, Laelaps differens Fonseca 1936, Laelaps manguinhosi Fonseca 1936, Tur lativentralis (Fonseca 1936), Gigantolaelaps goyanensis Fonseca 1939, Gigantolaelaps vitzthumi Fonseca 1939, Androlaelaps (Haemolaelaps) fahrenholzi (Berleze 1911), Eubrachylaelaps rotundus (Fonseca 1936) Mysolaelaps parvispinosus Fonseca 1936, Ctenophthirus cercomydis Ferris 1922, Hoplopleura imparata Linardi 1984, Eogyropus lenti lenti Werneck 1936, Tunga penetrans (Linnaeus 1758) and Polygenes tripus (Jordan 1933). All records are novel for the Park. Additionally, new mammalian hosts are added.

\section{KEY WORDS}

Brazil, Cerrado, National Park Serra do Cipó, mammals, ectoparasites.

\section{RESUMEN}

El objetivo del presente estudio fue investigar la prevalencia de infestación de ectoparásitos asociados a mamíferos pequeños del Cerrado en el Parque Nacional Serra do Cipó, Estado de Minas Gerais, Brasil. De abril a septiembre de 2007, capturamos 95 mamíferos pequeños, los cuales representaron nueve especies: seis pertenecen al Orden Rodentia: Cerradomys subflavus (Wagner 1842), Nectomys squamipes (Brants 1827), Thrichomys apereoides (Lund,1939), Rhipidomys mastacalis (Lund 1840), Necromys lasiurus (Lund 1841), Oligoryzomys nigripes Olfers 1818, y tres al Orden Didelphimorphia: Gracilinanus agilis (Burmeister 1854), Marmosops incanus (Lund 1840) y Didelphis albiventris (Lund,1841). Identificamos ectoparásitos de cinco órdenes: Ixodida, Gamasida, Phthiraptera, Siphonaptera y Diptera y varias especies de ectoparasitos como: Amblyomma sp, Laelaps paulistanensis Fonseca 1936, Laelaps differens Fonseca 1936, Laelaps manguinhosi Fonseca 1936, Tur lativentralis (Fonseca 1936), Gigantolaelaps goyanensis Fonseca 1939, Gigantolaelaps vitzthumi Fonseca 1939, Androlaelaps (Haemolaelaps) fahrenholzi (Berleze 1911), Eubrachylaelaps rotundus (Fonseca1936), Mysolaelaps parvispinosus Fonseca 1936, Ctenophthirus cercomydis Ferris1922, Hoplopleura imparata Linardi 1984, Eogyropus lenti lenti Werneck 1936, Tunga penetrans (Linnaeus 1758) y Poligenes tripus (Jordania 1933). Para el parque, son nuevos todos los registros de ectoparásitos y agregamos también algunos hospederos.

\section{PALABRAS CLAVE}

Brasil, Cerrado, Parque Nacional Serra do Cipó, mamíferos, ectoparásitos. 
The most common ectoparasites that infest small mammals belong mainly to the group of Ixodida (Ixodidae and Argasidae), Gamasida (Laelapidae and Macronyssidae), in the subclass of Acari; Siphonaptera (Rhopalopsyllidae) and Phthiraptera (Amblycera, Ischnocera and Hoplopleuridae) in the class of Insecta (Nieri-Bastos et al. 2004). Besides being an important component of the ecosystem and part of biodiversity, some of these ectoparasites have an extreme epidemiological importance as they act as vectors and host of various pathogenic for humans microorganisms causing world known serious diseases such as murine typhus, bubonic plague, tularemia or Lyme disease (Baker \& Wharton 1952, Abel et al. 2000). Although the ectoparasites of small mammals have ecologic, economic and public health importance, there are not many studies in Brazil (Graciolli et al. 2006). Most of the researches are concentrated on the southern and southeastern regions the country in floristic parts of the cities situated close to human settlements, where these ectoparasites are linked with human diseases (Fonseca 1958, Guedes et al. 2005, Barros-Batestti et al. 2006, Guglielmone et al. 2006). The studies are limited to the records of new species and taxonomical revisions, and there is a lack of researches concerning ecological relations between parasites and their hosts what has an extreme importance to understand the epidemiology of various diseases (Marshall 1981, Graciolli \& Aguiar 2002, Nava et al. 2003, Dias et al. 2009, Ribeiro et al. 2010).

The objective of the present work was to use ecological parameters of small mammals ectoparasite infestation to analyze relations between parasites and their mammalian hosts in the National Park Serra do Cipó, Minas Gerais State, Brazil.

\section{METHODOLOGY}

Small mammals captures were conducted in the National Park Serra do Cipó. The Park was created in 1984 and encompass an area of about 33800ha. It is located among Jaboticatubas, Santana do Riacho, Morro do Pilar and Itambé do Mato Dentro Municipalities in the state of Minas Gerais, Southeast Brazil (central point of the Park $19^{\circ} 20^{\prime} \mathrm{S}, 43^{\circ} 38^{\prime} \mathrm{W}$, elevation ranging from 900 to $1600 \mathrm{~m}$ ). The Park is located in the Cerrado biome, savannah-like ecosystem which one of the most important biodiversity hotspots in Brazil, and is characterised by an enormous range of plant and animal biodiversity (Myers et al. 2000, Eterovick \& Sazima 2004). The climate is humid subtropical with mild and rainy summers (annual rainfall ca. 1,500mm, October-March) and dry winters April-September with a mean annual temperature between 17 and $18,5^{\circ} \mathrm{C}$ (Galvão \& Nimer 1965).
The sampled areas were selected based on anterior study (Câmara et al. 2003). Five trails of $100 \mathrm{~m}$ long were chosen in five distinct areas of the Park. Small mammals were captured between April and September 2007, with 20 "live-trap" Shermann cages during four consecutive days each month, totalizing 600 hours/night of trapping effort. The bait was made of mixture of banana, oil from canned sardine, oat flour, peanut butter and maize and it was replaced every day. The captured rodents and marsupials were anesthetized with a piece of cotton soaked with sulfuric ether according to Barros-Battesti et al. (1998). We identified captured mammals to the species, banded, and examined them for the presence of ectoparasites, which were all collected for later identification. Nomenclature and identification of mammals follows Wilson \& Reeder (2005). Thereafter, all mammals were released at the same site. The ectoparasites were collected by brushing and combing over the white basin and immediately preserved in $70 \%$ ethanol for further identification. Tweezers were used when necessary. In the laboratory mites and fleas were mounted on slides according to the conventional techniques for Acari (Flechtmann 1975) and Siphonaptera (Linardi \& Guimarães 2000). Mites were identified following Fonseca (1935/36, 1939), fleas according to Linardi and Guimarães (2000), ticks according to Barros-Battesti et al. (2006), lice following Werneck (1942) and Ferris (1951), Dipteran larvae according to Baird (1983), Manrique-Saide et al. (2000) and Slansky (2006).

For each host species the following parameters were calculated: mean abundance of ectoparasites (MA- total number of individuals of a particular species of parasite in a sample of a particular host species / total number of hosts of this specie), the percentage $(P)$ of mammal individuals infested with ectoparasites (number of infested mammals / number of examined mammals $x 100$, for each mammal species) and the ectoparasites ratio between females and males (number of female ectoparasites of a particular species/ number of male ectoparasites of the same species) as described previously (Botelho 1990, Bush et al. 1997).

This study was licensed by the environmental agency responsible (Instituto Brasileiro de Meio Ambiente e Recursos Naturais Renováveis - IBAMA), with process number 10204-1.

\section{RESULTS}

A total of 95 mammals were captured, representing nine species. Six of these species belong to the order Rodentia: Cerradomys subflavus (Weksler 2006) (48 individuals); Nectomys squamipes (Brants 1827) (11 individuals); Thrichomys apereoides (Lund 1939) (9 individuals); 
Rhipidomys mastacalis (Lund 1840) (7 individuals); Necromys lasiurus (Lund 1841) (4 individuals) and Oligoryzomys nigripes Olfers 1818 (1 individual), and three to the Order Didelphimorphia - Gracilinanus agilis (Burmeister 1854) (3 individuals); Marmosops incanus (Lund 1840) (7 individuals) and Didelphis albiventris (Lund 1841) (5 individuals).

From captured mammals were collected ectoparasites form classes Aracnida and Insecta representing five orders: Ixodida, Gamasida, Phthiraptera, Siphonaptera and Diptera. The order Gamasida was represented by two Families: Laelapidae - Gigantolaelaps vitzthumi Fonseca 1939 (451 adults, 54 nymphs); Gigantolaelaps goyanensis Fonseca 1939 (102 adults, 43 nymphs); Laelaps differens Fonseca 1935 (818 adults, 100 nymphs); Laelaps manguinhosi Fonseca 1936 (105 adults, 19 nymphs); Laelaps paulistanensis Fonseca 1936 (92 adults, 22 nymphs); Tur lativentralis (Fonseca 1936) (496 adults, 87 nymphs); Androlaelaps (Haemolaelaps) fahrenholzi (Berleze 1911) (113 adults); Eubrachylaelaps rotundus (Fonseca 1936) (16 adults, 3 nymphs); Misolaelaps parvispinosus Fonseca 1936 (35 adults, 9 nymphs); and Macronyssidae (203 adults, 31 nymphs).

The order Phthiraptera was represented by Ctenophthirus cercomydis Ferris 1922 (Anoplura: Polyplacidae) (25 adults); Hoplopleura imparata Linardi et al. 1984 (Anoplura: Hoplopleuridae) (3 adults), and Eogyropus lenti lenti Werneck 1936 (Amblycera: Gyropidae) (80 adults, 9 nymphs). The order Siphonaptera was represented by Tunga penetrans (Linnaeus 1758) (Tungidae) (1 adult) and Poligenes tripus (Jordan 1933) (Rhopalopsyllidae) (7 adults). The order Diptera was represented by 9 larvae of Cuterebra sp.

Due to lack of specific literature and identification keys based on morphology not all collected ectoparasites were identified to the level of species thus ectoparasites Macronyssidae were identified only to the level of family. The ectoparasites from the family Oestridae and Ixodida were identified only to the level of genera Cuterebra sp. and Amblyomma sp., respectively. The detailed results of ectoparasites found during this work are shown in the Table 1 and 2.

The sex ratio was calculated for mites form the family Laelapidae, the fleas (Siphonaptera) and for lice (Phthiraptera). Others ectoparasites species were or collected in the immature stages or identified only to the level of family or genera hence were not included into analyses. The proportion of sex ratio of females to males was varying among species being higher for mites than for lice and fleas. In the case of mites, there was small numbers of males found or simply females were observed (Table 3 ).

\section{DISCUSSION}

The present study reports ectoparasites species parasitizing wild small mammals in a region of the Cerrado, Minas Gerais, southeast Brazil. All presented here records of ectoparasites are novel for the Park. The highest numbers of ectoparasites collected during this work belong to the order Gamasida what is in agreement with previous researches (Fonseca 1958, Botelho 1978, Barros-Battesti et al. 1998, Bossi et al. 2002, Lareschi et al. 2003, Nava et al. 2003, Nieri-Bastos et al. 2004). Especially the mites from the family Laelapidae are commonly found on small mammals. L. paulistanensis was found on all examined R. mastacalis and O. nigripes and on $2 \%$ of $C$. subflavus. According to literature $L$. paulistanensis parasitize commonly rodents from the genera Oligoryzomys and Oryzomys (Barros-Battesti et al. 1998, Botelho 1990) and have been already observed parasitizing all mentioned above species (Fonseca 1958, Nava et al. 2003, Lareschi et al. 2003). L. differens was found on $83,3 \%$ of C. subflavus and on $33,3 \%$ of $T$. apereoides. C. subflavus was already observed parasitized by this mite by Botelho (1990), but T. apereoides is shown for the first time to serve as a host for this species. L. manguinhosi was found on $82 \%$ of $N$. squamipes and on $25 \%$ of $N$. lasiurus. This mite is frequently found on small semiaquatic rodents form the genera Nectomys and Holochilus (Fonseca 1936, Martins-Hatano et al. 2002), and is occasionally found on other species of rodents and birds (Fonseca \& Trindade 1958, Gettinger 1992).

The species $T$. latreventralis was found on all examined T. apereoides, and on two species of marsupials G. agilis and D. albiventris with the prevalence 33,3 and $20 \%$ respectively what is in concordance with the previous results of Fonseca (1958). In the present study G. goyanensis was found exclusively on N. squamipes (91\%). This result is similar with the studies of Fonseca (1939) and Botelho (1978), and the latter defined N. squamipes as the main host of this parasite. Esberrard et al. (2005), Gettinger (1987) and Martins-Hatano et al. (2002) found high levels of infestation of N. squamipes as well, however, they found additionally Oxymycterus dasytrichus (Schinz 1821) and Trinomys dimidiatus (Günther 1877) being parasitized by G. goyanensis. G. vitzthumi was found exclusively on C. subflavus (89,6\%). Its narrow preference to C. subflavus, defined by Botelho (1990) as the main host for this parasite, was also found in other resarches (Fonseca 1958, Gettinger 1987, Botelho 1990). In the contrast, the mite $A$. fahrenholzi showed the low level of preference to host; it was found on five from all nine species captured (C. subflavus, N. squamipes, T. apereoides, N. lasiurus and M. incanus). Following Strandtmann \& Wharton (1958), A. fahrenholzi is cosmopolite specie fond on variety of mammals around 


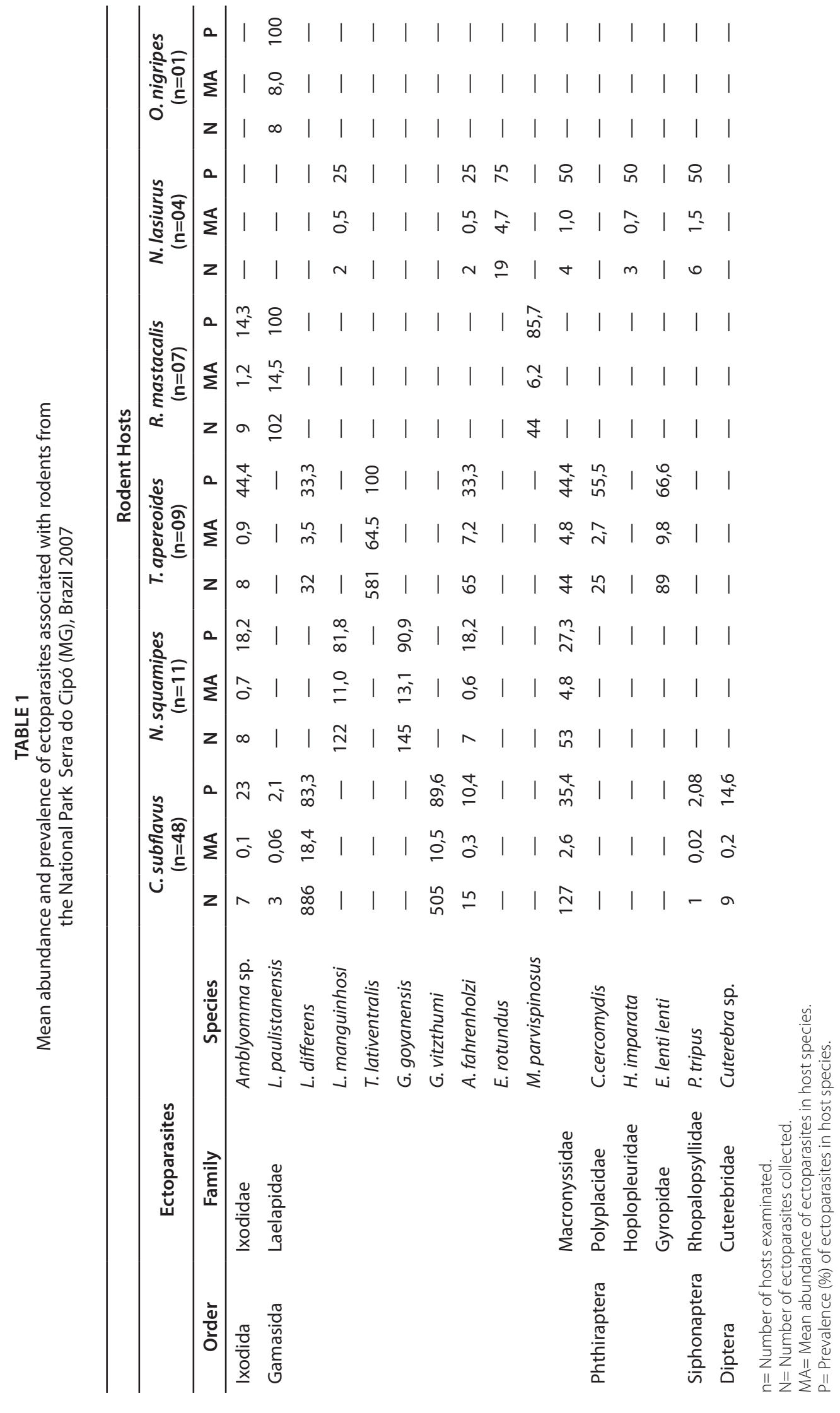


TABLE 2

Mean abundance and prevalence of ectoparasites associated with marsupials from the National Park Serra do Cipó (MG), Brazil 2007

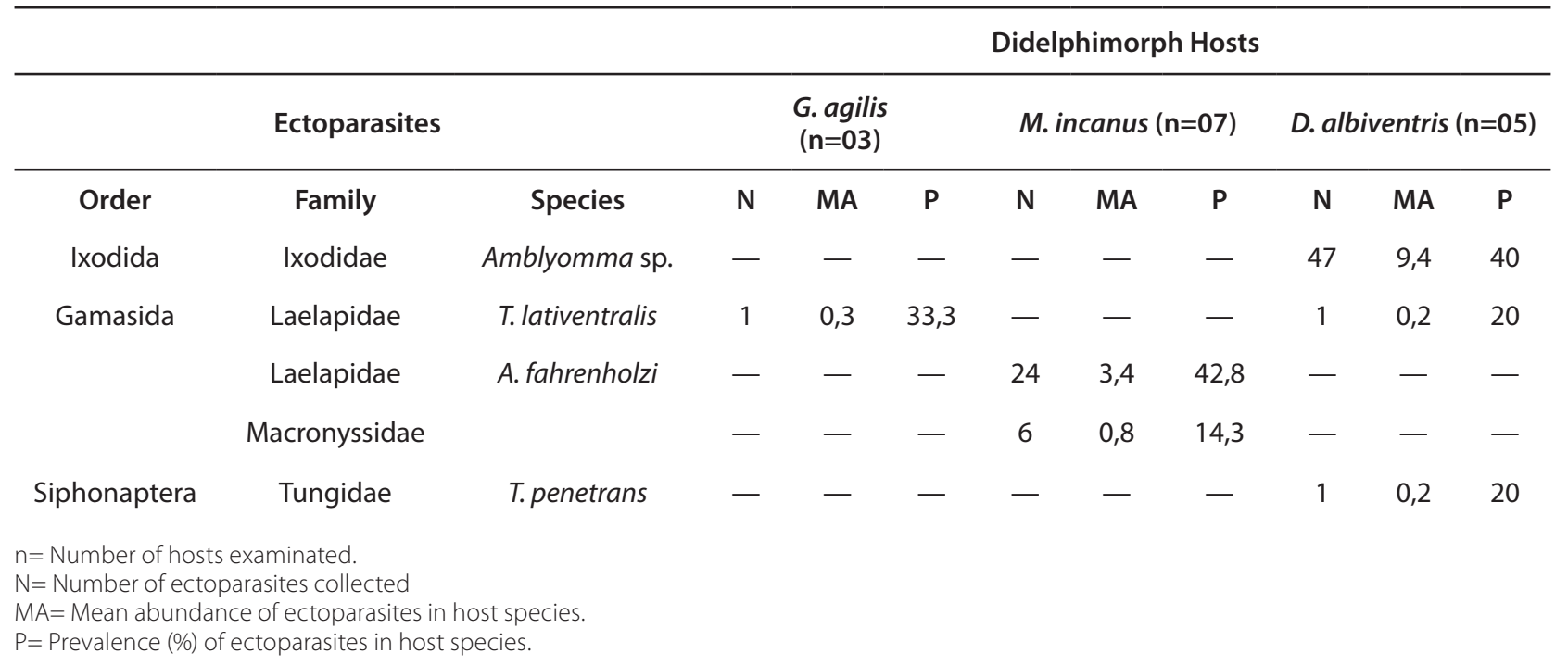

TABLE 3

Proportion of females to males of ectoparasites collected in the National Park Serra do Cipó (MG), Brazil 2007

\begin{tabular}{lccc}
\hline \multirow{2}{*}{ Species } & \multicolumn{2}{c}{ Sex } & Proportion \\
\cline { 2 - 4 } & Female & Male & Female/Male \\
\hline L. paulistanensis & 113 & 0 & - \\
L. differens & 865 & 7 & 123,6 \\
L. manguinhosi & 124 & 0 & - \\
T. lativentralis & 295 & 87 & 3,4 \\
G. goyanensis & 135 & 10 & 13,5 \\
G. vitzthumi & 490 & 6 & 81,6 \\
A. fahrenholzi & 113 & 0 & - \\
A. rotundus & 19 & 0 & - \\
M. parvispinosus & 44 & 0 & - \\
P. tripus & 4 & 3 & 1,33 \\
T. penetrans & 1 & 0 & - \\
C.cercomydis & 15 & 10 & 1,5 \\
H. imparata & 1 & 2 & 0,5 \\
E. lentilenti & 48 & 32 & 1,5 \\
& & &
\end{tabular}

the world. In Brazil was already previously registered on N. lasiurus, C. subflavus. (Botelho 1990), Akodon sp. (Lareschi et al. 2003, Nava et al. 2003), O. nigripes, Oxymicterus sp., Sciurus aestuans Linnaeus 1766 (Barros-Battesti et al. 1998), Scapteromys aquaticus Thomas 1920, and Holochilus brasiliensis Thomas 1897 (Nava et al. 2003). To our knowledge, this is the first time that $N$. squamipes and $T$. apereoides were found parasitized by this mite.

The mite $E$. rotundus was found on $75 \%$ examined $N$. lasiurus. Different studies demonstrated the preference of this species to the genera Necromys (Fonseca 1958, Botelho 1990, Gettinger \& Owen 2000) and Akodon (Botelho 1978, Linardi et al. 1991, Barros-Battesti et al. 1998, Lareschi et al. 2003) and to the species C. subflavus and N. squamipes (Fonseca \& Trindade 1958). The species M. parvispinosus was found exclusively on $R$. mastacalis (86\%). This parasite was commonly found during other studies on Oligoryzomys eliurus (synonym to O. nigripes) (Barros-Battesti 1998, Linardi et al. 1991), C. subflavus (Fonseca 1958), Oryzomys matogrossae (Botelho 1978) and on Oryzomys utiaritensis (Botelho 1990). Here we add for the first time one more host of this parasite.

Mites from the family Macronyssidae were collected from rodents $C$. subflavus, $N$. squamipes, $T$. apereoides and $N$. lasiurus, and also from marsupial $M$. incanus. Fonseca (1936) found the parasites from this family on Cavia aperea (Erxleben 1777), Didelphis marsupialis Linnaeus 1758, Nectomys squamipes, Gracilinanus microtarsus (Wagner 1842), 
Oxymicterus judex (Thomas 1909) and Sylvilagus brasiliensis (Linnaeus 1758). However, the lack of accurate species descriptions makes very difficult to evaluate the systematic position and of many species registered.

Various larvae of ticks form the genera Amblyomma were found on C. subflavus (23\%), N. squamipes $(18,2 \%)$, T. apereoides $(44,4 \%), R$. mastacalis (14\%) and on D. albiventris $(40 \%)$. Small rodents form these genera are rarely found infested by the ticks Amblyomma (Figueiredo et al. 1999, Brum et al. 2003, Muller et al. 2005). On the other hand, there are records of frequent parasitism of ticks form the genera Ixodes (Barros-Battesti et al. 2000; Evans et al. 2000). Because most of the $\approx 30$ Amblyomma species currently known to occur in Brazil have their larval stages still not described (Guglielmone et al. 2003); consequently, there is no sufficient literature for a proper identification of Brazilian Amblyomma larvae and records are limited to genus level (Amblyomma sp.).

Among the order Phthiraptera three species of lice were identified: $C$. cercomydis and $E$. lenti lenti were found exclusively on $T$. apereoides with the prevalence 55,5 and $66,6 \%$ respectively and $H$. imparata only on the $N$. lasiurus (50\%). All species of lice were collected on their host-type, according to Ferris (1951), Werneck (1942) and Linardi et al. (1984).

Two species of Siphonaptera were found in the present study; T. penetrans was found on D. albiventris ( 1 adult) and $P$. tripus were found on $C$. subflavus ( 1 adult) and on $N$. lasiurus (7 adults). Such a low number of fleas can be related with the fact that these insects parasite their host in the adult stage and most of the time they spent hiding rather in the nest of animals (Linardi et al. 1997). Beside this fact the fleas are know to leave its host in the stressful situation what happens during animals captures (Botelho 1990). According to literature, P. tripus is known as a frequent parasite of Akodon sp. (Botelho 1978, Barros-Battesti et al. 1998) and Necromys sp. (Botelho 1990). However, $N$. lasiurus and $C$. subflavus have been also previously found parasitized by this species (Botelho 1990). The flea T. penetrans is found on various types of mammals such as carnivores, ungulates and xenarthrans (Linardi \& Guimarães 2000). The opossums $D$. albiventris has been already observed being parasitized by this specie and the fact that only one individual was found might be due to low number of captured hosts.

Apart from discussed ectoparasites, the larvae of $\mathrm{Cu}$ terebra sp. (Diptera: Oestridae) were found on $14,6 \%$ of C. subflavus. This fly is endemic to the New World and is and opportunist endoparasite found mainly on mammals (Guimarães \& Papavero 1999). Its larvae leave in the subcutaneous tissues of their hosts for few weeks feeding on body breathing through the hole in the skin of their hosts (Slansky 2006). The larvae from the genus Cuterebra have been previously found on rats and on rabbits (lagomorfos) (Manrique-Saide et al. 2000), however here we relate the $C$. subflavus serving as host for this parasite for the first time.

The observed differences in the number of females and males among mites are noteworthy; the females were more abundant and in some cases no male was seen what is in concordance with other studies (Fonseca 1939, Fonseca 1958, Botelho 1978, Linardi et al. 1985, Lopes 1989, Botelho 1990). Numerous factors can explain this phenomenon. One of them is the fact that the mites have capacity to reproduce by parthenogenesis (Baker \&Wharton 1952), the mite males live also shorter than females (Willians \& Kershaw 1977). In various species from the family Laelapidae males and immature forms live inside the nest of host parasitizing him only for a short time, while females need to feed with higher frequency to produce eggs after blood meal, thus they accompany their host most of the time (Flechtmann 1975).

Among fleas the ratio of females to males was observed similar to other studies (Cerqueira 1975, Linardi 1977, Cerqueira \& Linardi 1977, Lopes 1989, Botelho 1990). Following the theory of Linardi \& Nagem (1972), slight variation between the number of females and males is a result of the difference of longevity reproductive cycles.

All presented here records of mammals ectoparasites are novel for the Park. Several species of ectoparasites have great ecological importance as part of the community structure of small mammals, which can reduce competitive ability and increase vulnerability of hosts to predators; evolutionary importance, offering great information related to the dynamics of past populations, which currently are extinct but preserve features closely related due to the co-evolution of host-parasite, and also environmental importance, since some species can serve as effective indicators of environmental quality (Komplen et al. 1996, Morand et al. 2006).

Additionally, ticks, mites and fleas are among the most important vectors of pathogens that cause diseases in human and domestic and wild animals (Jongejan \& Uilenberg 2004). For example, ticks Amblyomma are principal vectors of bacterium Rickettsia rickettsii, the agent of Brazilian Spotted Fever in the South America (Labruna 2009) and mites Macronyssidae are suspected to be involved in the circulation of the bacteria in the natural environment (Reeves et al. 2006, 2007). Therefore, further studies concerning the ectoparasites and pathogens that they may transmit are urgently needed. 


\section{ACKNOWLEDGMENTS}

We thank the staff of PUC Minas Museum of Natural Sciences and Parasitology Laboratory of the Federal University of Minas Gerais for technical support, and Michel P. Valim, for identification of part of the Phthiraptera.

\section{REFERENCES}

Abel, I.S., D.E. Almeida-Junior, A.H. Fonseca, C.O. Soares \& M.M. Ishikawa. 2000. Borrelia sp. in naturally infected Didelphis aurita (Wied, 1826) (Marsupialia: Didelphidae). Brazilian archive Biology and Technology 43: 307-312.

Baird, C.R. 1983. Biology of Cuterebra lepusculi Townsend (Diptera: Cuterebriae) in Conttontail Rabbits in Idaho. Journal of Wildlife Diseases 19: 214-218.

Baker, E.W. \& G.W. Wharton. 1952. An Introduction to Acarology. New York, The Macmillan Company, New York, USA

Barros-Battesti, D.M., M. Arzua, P.M. Linardi, J.R. Botelho \& I.J. Isbalquero. 1998. Interrelationship between Ectoparasites and Wild Rodents from Tijucas do Sul, State of Paraná, Brazil. Memórias do Instituto Oswaldo Cruz 93: 719-725

Barros-Battesti, D.M., N.H. Yoshinari, V.L.N. Bonoldi \& A.C. Gomes. 2000. Parasitism by Ixodes didelphidis and I. loricatus (Acari: Ixodidae) on Small Wild Mammals from an Atlantic Forest in the State of Sao Paulo, Brazil. Journal de Medicina Entomológica 37: 820-827

Barros-Battesti, D.M., M. Arzua \& G.H. Bechara. 2006. Carrapatos de importância médicoveterinária da região neotropical: um guia ilustrado para identificação de espécies. Butantan, São Paulo, Brasil

Bossi, E.P., A.X. Linhares \& H.G. Bergallo. 2002. Parasitic arthropods of some wild rodents from Juréia-Itatins ecological station, state of São Paulo, Brazil. Memórias do Instituto Oswaldo Cruz 97: 959-963

Botelho, J.R. 1978. Ectoparasitos de Roedores Silvestres do Município de Caratinga, Minas Gerais. Belo Horizonte, Universidade Federal de Minas Gerais, Minas Gerais, Brazil

Botelho, J. R. 1990. Ectoparasitos de alguns roedores de Belo Horizonte, MG. Estudos fenéticos, cladísticos e de interação parasito/hospedeiro. Belo Horizonte, Universidade Federal de Minas Gerais, Departamento de Parasitologia, Editorial, Belo Horizonte, Brazil

Brum, J.G.W., A.L.S. Valente, A.P. Albano, M.A.C. Coimbra \& G.C. Greque. 2003. Ixodidae de Mamíferos Silvestres Atendidos no Núcleo de Reabilitação de Fauna Silvestre, UFPEL. Arquivo do Instituto de Biologia 70: 211-212

Bush, A. O., K.D. Lafferty, J.M. Lotz \& A.W. Shostak. 1997. Parasitology meets ecology on its own terms: Margolis et al. Revisited. Journal Parasitologia 83: 575-583

Câmara, T. \& R. Murta. 2003. Mamíferos da Serra do Cipó, Belo horizonte, Museu PUC Minas de Ciências Naturais, Minas Gerais, Brazil
Cerqueira, H.J.L. 1975. Polygenis tripus (Jordan, 1933) (siphonaptera, Rhopalopsyllidae). Binômia e relações hospedeiroparasito observadas no município de Belo Horizonte, MG. Belo Horizonte, Instituto de Ciências Biológicas, Universidade de Minas Gerais, Minas Gerais, Brazil

Cerqueira, E.L.J. \& P.M. Linardi. 1977. Índices Pulicidianos em Belo Horizonte, Minas Gerais, Brasil. Revista Ciêntífica Cultural 29: 191-194.

Dias, P.A., C.L.C. Santos, F.S. Rodrigues, L.C. Rosa, K.S. Lobato \& J.M.M. Rebêlo. 2009. Espécies de moscas ectoparasitas (Diptera, Hippoboscoidea) de morcegos (Mammalia, Chiroptera) no estado do Maranhão. Revista Brasileira de Entomologia 53: 128-133.

Esbérard, C.E.L., F. Martins-Hatano, E.B. Bittencour, D.E.P. Bossi, A. Fontes, M. Lareschi, V. Menezes, H.G. Bergallo \& D.A. Gettinger. 2005. method for testing the host specificity of ectoparasites: give them the opportunity to choose. Memórias do Instituto Oswaldo Cruz 100: 761-764

Eterovick, P.C. \& I. Sazima. 2004. Anfíbios da Serra do Cipó, MG. PUC, Minas Gerais, Brazil

Evans, D.E., J.R. Martins \& A.A. Guglielmone. 2000. A review of the ticks (Acari: Ixodidae) of Brazil, their hosts and geographic distribution - 1 The state of Rio Grande do Sul, Southern Brazil. Memórias do Instituto Oswaldo Cruz 95: 453-470

Figueiredo, L.T.M., S.J. Bradal \& L.E. Pereira. 1999. Report on ticks collected in the Southeast and Mid-West regions of Brazil: analyzing the potential transmission of tick-borne pathogens to man. Revista da Sociedade Brasileira de Medicina Tropical 32: 613-619

Ferris, G.F. 1951. The sucking lice. Memoirs of the Pacific Coast Entomological Society 1: 1-320

Flechtmann, C.H.W. 1975. Elementos de Acarologia. Nobel, São Paulo, Brazil

Fonseca, F. 1935. Notas de Acareologia XIII. Novas espécies sulamericanas de parasitos do gênero Lyponyssus Kolenati, 1858 (Acari, Liponissidae). Memórias do Instituto Butan$\tan 9: 60-114$

Fonseca, F. 1936. Notas de Acareologia. XX. Espécies de Acarinos do gênero Laelaps, parasitos de ratos no Brasil (Acari, Laelaptidae). Memórias do Instituto Butantan 10: 33-37

Fonseca, F. 1939. Notas de Acareologia. Os Laelaptidae gigantes, parasitas de roedores sul-americanos; gênero e espécies novos (Acari). Memórias do Instituto Butantan 5: 1-25

Fonseca, F. Notas de Acarologia. 1958. XLIV Inquérito sobre a fauna acarológica de parasitas no nordeste do Brasil. Memórias do Instituto Oswaldo Cruz 28: 99-186

Fonseca, F. \& G. Trindade. 1958. XLIII Fauna Acarológica de Roedores de Ouro Preto. Notas de Acarologia 28: 59-66

Galvão, M.V. \& E. Nimer. 1965. Geografia do Brasil, Grande Região Leste: Clima. Rio de Janeiro. Conselho Nacional de Geografia, IBGE, Rio de Janeiro, Brazil. 
Gettinger, D. 1987. Host Associations of Gigantolaelaps (Acari: Laelapidae) in the Cerrado Province of Central Brazil. Entomological Society of America 24: 561-565

Gettinger, D. 1992. Host specificty of Laelaps (Acari: Laelapidae) in Central Brasil. Journal of Medicinal Entomology 29: 827-833

Gettinger, D. \& R.D. Owen. 2000. Androlaelaps rotundus Fonseca (Acari: Laelapidae) associated with akodontine rodents in Paraguay: a morphometric examination of a pleioxenous ectoparasite. Revista Brasileira de Biologia 60: 425-434

Graciolli, G \& L.S. Aguiar. 2002. Ocorrência de moscas ectoparasitas (Diptera, Streblidae e Nycteribiidae) de morcegos (Mammalia, Chiroptera) no Cerrado de Brasília, Distrito Federal, Brasil. Revista Brasileira Zoologia 19: 177-181

Graciolli, G., N.C. Cáceres \& M.R. Bornchein. 2006. Novos registros de moscas ectoparasitas (Díptera, Streblidae e Nycteribiidae) de morcegos (Mammalia, Chiroptera) em áreas de transição cerrado-floresta estacional no Mato Grosso do Sul, Brasil. Biota Neotropical 6: 1-4

Guedes, R.N.C., E.E. Oliveira, N.M.P. Guedes, B. Ribeiro. \& J.E. Serrão. 2005. Cost and mitigation of insecticide resistance in the maize weevil, Sitophilus zeamais. Physiological Entomology 31: 30-38

Guglielmone, A.A., A. Estrada-Peña, J.E. Keirans \& R.G. Robbins. 2003. Ticks (Acari: Ixodidae) of the Neotropical Zoogeographic Region. Center For Infectious Diseases at the Centers for Disease Control, Georgia, USA.

Guglielmone A.A., L. Beati, D.M. Barros-Battesti, M.B. Labruna, N. Nava, J.M. Venzal, A.J. Mangold, M.J.P. Szabó \& J.R. Martins. 2006. Ticks (Ixodidae) on humans in South America. Experimental and Applied Acarology 40: 83-100

Guimarães J.H. \& N. Papavero. 1999. Myiasis and animals in the neotropical region: bibliographic database. Plêidate, São Paulo, Brazil

Jongejan, F. \& G. Uilenberg. 2004. The global importance of ticks. Parasitology 129: 3-14

Klompen, J.S.H., W.C. Black, J.E. Keirans \& J.H. Oliver. 1996. Evolution of Ticks. Annual Review of Entomology 41: 141-161

Labruna, M.B. 2009. Ecology of Rickettsia in South America. Annals of New York Academy of Science 1166: 156-66

Lareschi, M., J. Notarnicola, G. Navone. \& P.M. Linardi. 2003. Arthropod and Filarioid Parasites Associated with Wild Rodents in the Northeast Marshes of Buenos Aires, Argentina. Memórias do Instituto Oswaldo Cruz 85: 673-677

Linardi, P.M. 1977. Relações pulgas/ roedores observadas nos municlpios de Salesópolis e Itapetininga, SP. Boletim do Museu de História Natura 23:1-25

Linardi, P.M., J.R. Botelho, D.P. Neves \& H.C. Cunha. 1984. Sobre alguns ectoparasitos de roedores silvestres de Belo Horizonte. Revista Brasileira de Biologia 44: 215-219

Linardi, P.M., J.R. Botelho \& H.C. Cunha. 1985. Ectoparasitos de Roedores da Região Urbana de Belo Horizonte, MG. III. Índices Pulicidianos, anoplurianos e acarianos em Rattus norvergicus norvergicus. Memórias do Instituto Oswaldo Cruz 80: 277-284.

Linardi, P.M., V.P. Teixeira, J.R. Botelho \& L.S. Ribeiro. 1987. Ectoparasitos de roedores em ambientes silvestres do $\mathrm{Mu}$ nicípio de Juiz de Fora, Minas Gerais. Memórias do Instituto Oswaldo Cruz 82: 137-139

Linardi, P.M., J.R. Botelho, A. Ximenez \& C.R. Padovani. 1991. Notes on Ectoparasites of Some Small Mammals from Santa Catarine State, Brazil. Jornal of Medical Entomology 28: 183-185

Linardi, P.M. \& L.R. Guimarães. 2000. Sifonápteros do Brasil. MZUSP/Fapesp, São Paulo, Brazil.

Linardi, P.M. \& R.L. Nagem. 1972. Observações sobre o ciclo evolutivo de Ctenocephalides felis felis (Bouché,1835) (Siphonaptera: Pulicidae) e sua sobrevida fora do hospedeiro. Boletins do Museu de História Natural 13: 1-23

Lopes, C.M.L. 1989. Ectoparasitos de roedores domiciliares campestres e silvestres do Município de Tiradentes, MG. Belo Horizonte, Universidade Federal de Minas Gerais, Minas Gerais, Brazil

Manrique-Saide, P., S. Hernandez-Betencourt, \& M.T. Quitero. 2000. First Record of Cuterebra sp. (Diptera: Cuterebridae) Infection in Ototylomys phyllotis (Rodentia: Muridae). Scientific Notes 83: 487-488

Marshall, A.G. 1981. The Ecology of Ectoparasitic Insects. United Kingdom, Department of Zoology, Aberdeen. Aberdeen University, Academic, London, UK

Martins-Hatano, F., D. Gettinger \& H.G. Bergallo. 2002. Ecology and Host Specificity of Laelapine Mites (Acari: Laelapidae) of Small Mammals in an Atlantic Forest Area of Brazil. American Society of Parasitologists 88: 36-40

Morand, S., B.R. Krasnov, R. Poulin. 2006. Micromammals and Macroparasites - From Evolutionary Ecology to Management. Springer, New York, USA

Muller, G., J.G.W. Brum, P.Q. Langone, G.H. Michels \& T.C. Pesenti. 2005. Amblyomma aureolatum (Acari: Ixodidae) parasitizing Didelphis albiventris (Marsupialia: Didelphidae) in the state of Rio Grande do Sul. Arquivos do Instituto Biológico 72: 115-116.

Myers, N., R.A Mittermeier, C.G. Mittermeier, G.A.B. Fonseca \& J. Kent. 2000. Biodiversity hotspots for conservation priorities. Nature 403: 853-858

Nava, S., M. Lareschi \& D. Voglino. 2003. Interrelationship between ectoparasites and wild rodents from northeastern Buenos Aires province, Argentina. Memórias do Instituto Oswaldo Cruz 98: 45-49

Nieri-Bastos, F.A., D.M. Barros-Battesti, P.M. Linardi, M. Amaku, A. Marcili, S. Favorito. E. \& R. Pinto-da-Rocha. 2004. Ectoparasites of wild rodents from Parque Estadual da Cantareira (Pedra Grande Nuclei), São Paulo, Brazil. Revista Brasileira de Parasitologia Veterinária 13: 29-35

Ribeiro, K.R; G.F.S. Rocha, D.G. Saraiva, A.P. Silva, D.A.R. Vilela, P.C.S. Lima, I.B. Campos, D.C. Filippo, J.S. Nascimento \& S.B. Calic. 2010. Das capivaras das capivaras e carrapatos 
a uma proposta de comunicação e manejo no parque nacional da serra do cipó para redução de riscos à saúde. Oecologia Australis 14: 668-685.

Reeves, W., A. P. G. Dowling \& G. A. Dasch, 2006. Rickettsial agents from parasitic Dermanyssoidea (Acari: Mesostigmata). Experimental and Applied Acarology 38: 181-188

Reeves, W. K., A. D. Loftis, D. E. Szumlas, M. Abbassy, I. M. Helmy, H. A Hanafi \& G. A. Dasch,. 2007. Rickettsial pathogens in the tropical rat mite Ornithonyssus bacoti (Acari: Macronyssidae) from Egyptian rats (Rattus spp.). Experimental and Applied Acarology 41: 101-107

Slansky, F. 2006. Cuterebra bot flies (Diptera: Oestridea) and their indigenous hosts and potencial hosts in Florida. Florida Entolmologist 89: 152-161
Strandtmann, R.W.\& G.W. Wharton. 1958. Manual of Mesostigmatid Mites. Institute of The Acarology. CE Yunker, California, USA.

Werneck, F.L. 1942. Os Malófagos dos Punarés. Revista Brasileira de Biologia 2: 17-27.

Willians, P. \& W.E. Kershaw. 1977. Studies on the intake of microfilaria by their insect vectors. X. The survival of the neotropical rate mit, the vector of filariasis in the cotton rat. Annals of Tropical Medicine Parasitology 88: 255-258.

Wilson, D.E. \& D.M. Reeder. 2005. Mammal Species of the World. Johns Hopkins University, Maryland, USA. 
